\title{
PDO and PGI as ingredients of other products
}

\author{
Alberto Ribeiro de Almeida \\ Instituto dos Vinhos do Douro e do Porto, Porto, Portugal
}

\begin{abstract}
Geographical indications and designations of origin are industrial property rights. Some may have a strong distinctive power in order to attract the consumer even if the geographical indication or designation of origin is used in a non-comparable product. There is another problem: use of the geographical indication or designation of origin as an ingredient in another product. A true indication does not mean a loyal indication on trade.
\end{abstract}

\section{Introduction}

Geographical indications and designations of origin are industrial property rights. Some may have a strong distinctive power in order to attract the consumer even if the geographical indication or designation of origin is used in a non-comparable product.

There is another problem: use of the geographical indication or designation of origin as an ingredient in another product. A true indication does not mean a loyal indication on trade.

Besides, we must distinguish between descriptive uses and distinctive uses.

\section{Non-comparable products}

Designations of origin and geographical indications are industrial property rights. The level of protection at the European and national level has to take into account its legal nature and its function.

There must be rules to protect designations of origin and geographical indications even for non-comparable or nonsimilar products where there is a risk of dilution or a risk to the distinctive character of the designation of origin and geographical indication or that use would take unfair advantage of the designation of origin and geographical indication.

There has been different interpretation of the rules in force in the European Union. We also have different decisions on several European Union member states. We should look to the protection conceded to trademarks, specially the prestigious ones. Shouldn't designations of origin and geographical indications have a similar protection?

Use of the name of the designation of origin or geographical indication on the identification of a complete different product may create a risk of dilution or a risk to the distinctive character of the designation of origin or geographical indication or that use may take unfair advantage of the designation of origin or geographical indication. Use the product that has the right to use the designation of origin and geographical indication as an ingredient of that complete different product is not a fair excuse.

\section{Ingredients}

The main problem addressing here is the possibility or impossibility of use the name of a designation of origin or geographical indication in a complete different product, when this product incorporates a certain percentage of the product that has the right to use a designation of origin and geographical indication. Is this only a labeling problem?

Namely, is this only a problem on distinguishing descriptive uses from distinctive uses? Or, is it a problem that must be analyzed on the framework of intellectual property rights rules?

The use of a product with a geographical indication or a designation of origin as an ingredient of another product is allowed. Is this case it is also possible to indicate on the list of ingredients of that product (for example chocolate) that it contains, for example, a wine with a designation of origin or with a geographical indication.

The main issue is when that product (chocolate, for examples) indicates the designation of origin or the geographical indication as the name of the product or as the distinctive sign of that product. That is, when it uses the designation of origin or the geographical indication as generic term or as a distinctive sign, like a trade mark.

These are dangerous uses of the designation of origin or the geographical indication (all of the prestigious names on the market) that has the following consequences:

a) Dilution of the distinctive power of the designation of origin or the geographical indication;

b) Risk to the distinctive character of the designation of origin and geographical indication;

c) Take unfair advantage of the designation of origin and geographical indication;

d) Contribute to its degeneration.

Let's see some examples:

a) PDO PORTO versus European trademark "DIPORTOFINO" for coffee, tea, cocoa, sugar, rice, bread, ice-cream, honey, salt, spices, sauces, etc. The OHIM said: "the applicant would benefit from the 
fame of the traditional appellation of origin PORTO (...) it takes unfair advantage of the distinctive character and the prestige of the appellation of origin".

b) «FOIS GRAS DE CANARD AUX POIVRES ET AU CHAMPAGNE ». The French court said the following: « (...) risque de détournement et d'affaiblissement de notoriété de l'appellation ».

c) «MAC CHEESE recette au Beaufort fondu »; «MAC CHEESE sauce au Reblochon »; «MAC CHEESE sauce à la Tomme de Savoie fondue ». The French court said: « (...) n' avait eu pour but que de tirer indument profit en les affaiblissant et en les dévalorisant, de la réputation et de la notoriété de ces AOC et IGP (...) discréditer la qualité $(. .)$.$» .$

\section{Conclusion}

In all the cases that we saw above, the problem is not protecting the consumer or misleading the consumer.

The problem is the protection of the investment made by producers and traders on the use of the designation of origin or geographical indication. This investment can be lost if the designation of origin or the geographical indication is used widely in several products.

Finally, this only happens when we are facing designations of origin or geographical indications that have great distinctive power. Why is that? Is that a coincidence? 